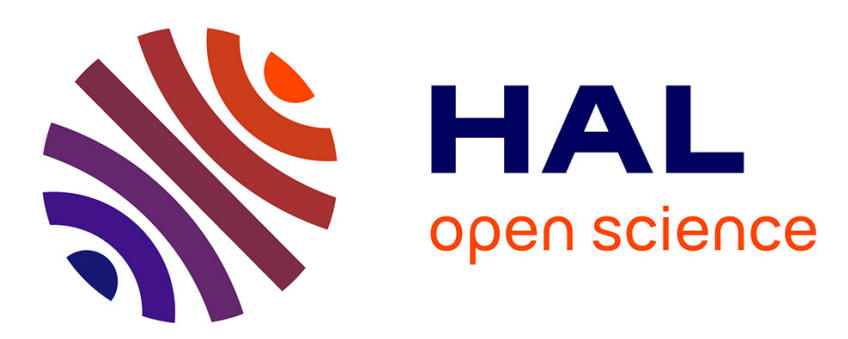

\title{
Scaling effect for estimating soil loss in the RUSLE model using remotely sensed geospatial data in Korea
}

G.-S. Lee, K.-H. Lee

\section{To cite this version:}

G.-S. Lee, K.-H. Lee. Scaling effect for estimating soil loss in the RUSLE model using remotely sensed geospatial data in Korea. Hydrology and Earth System Sciences Discussions, 2006, 3 (1), pp.135-157. hal-00298647

\section{HAL Id: hal-00298647 \\ https://hal.science/hal-00298647}

Submitted on 16 Feb 2006

HAL is a multi-disciplinary open access archive for the deposit and dissemination of scientific research documents, whether they are published or not. The documents may come from teaching and research institutions in France or abroad, or from public or private research centers.
L'archive ouverte pluridisciplinaire $\mathbf{H A L}$, est destinée au dépôt et à la diffusion de documents scientifiques de niveau recherche, publiés ou non, émanant des établissements d'enseignement et de recherche français ou étrangers, des laboratoires publics ou privés. 
Hydrol. Earth Syst. Sci. Discuss., 3, 135-157, 2006

www.copernicus.org/EGU/hess/hessd/3/135/

SRef-ID: 1812-2116/hessd/2006-3-135

European Geosciences Union
Hydrology and

Earth System

Sciences

Discussions

Papers published in Hydrology and Earth System Sciences Discussions are under open-access review for the journal Hydrology and Earth System Sciences

\section{Scaling effect for estimating soil loss in the RUSLE model using remotely sensed geospatial data in Korea}

\section{G.-S. Lee and K.-H. Lee}

Korea Water Resource Corporation, 462-1 Jeonmin-dong, Yusung-gu, Daejeon, Korea

Received: 1 November 2005 - Accepted: 7 January 2006 - Published: 16 February 2006

Correspondence to: G.-S. Lee (ilovegod@kowaco.or.kr)

(C) 2006 Author(s). This work is licensed under a Creative Commons License.

\section{HESSD}

3, 135-157, 2006

Scaling effect for soil loss in the RUSLE in

Korea

G.-S. Lee and K.-H. Lee

Title Page

Abstract

Introduction

Conclusions

References

Tables

Figures

14

4

Back

Print Version

Interactive Discussion 


\section{Abstract}

Accurate estimation of soil loss/deposition forced by rainfall events plays a major role in water resources management and it directly affects the quality of agricultural land and water storage capacity in reservoirs. In this paper, the soil loss model, Revised 5 Universal Soil Loss Equation (RUSLE) was used to quantify soil loss in a small basin located in southern part of Korea. The surface characteristics, such as soil texture, elevation, and vegetation type, are needed to run the RUSLE model. Remotely sensed geospatial data has been successfully used to derive suitable model factors for this purpose. It is, however, difficult to select the grid size of elements for the best fit, which is, often, decided in a subjective and intuitive way. A GIS spatial analysis was performed to investigate the scaling effect for estimating soil loss in the RUSLE model using the remotely sensed geospatial data. The results show that the L- and S- factors are sensitive to the grid size and the optimal resolution to quantify soil loss in the RUSLE model for the study site is $125 \mathrm{~m}$. This approach presents a method to select the suitable scale for estimating soil loss using the remotely sensed geospatial data and eventually improve the prediction of soil loss in a basin scale.

\section{Introduction}

In Korea, extremely heavy rainfall events over the last decade have been increasing, which has an effect on runoff, erosion, soil moisture distribution, irrigation, ecological conditions, and design and planning. Especially, soil loss has been a threat to farm livelihoods and ecosystem integrity and accurate estimation of soil loss/deposition forced by heavy rainfall events is urgently needed to effectively control both the natural and accelerated erosion. Yet, not many studies have been made to quantitatively predict soil loss and those that have been made were primarily on a numerical modeling basis because of difficulties in the measurement of soil loss (Renard et al., 1998; Yitayew et al., 1999). It is, in fact, impossible to consider all forms of erosion with a model

\section{HESSD}

3, 135-157, 2006

\section{Scaling effect for soil loss in the RUSLE in Korea}

G.-S. Lee and K.-H. Lee

\section{Title Page}

\section{Abstract} Introduction

Conclusions References

Tables Figures

14

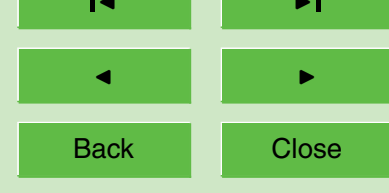

Full Screen / Esc

Print Version

Interactive Discussion

EGU 
thus, mostly, models have been developed to investigate specific problems.

The RUSLE model, which is an updated version of the Universal Soil Loss Equation (USLE) model (Wischmeier and Smith, 1978), has been widely used to estimate the average annual soil loss per unit land area that is associated with rill and sheet ero5 sion and the RUSLE is well suited for predicting water induced erosion in temperate climates (Renard et al., 1998). With the RUSLE model, the average annual rate of soil loss for a site of interest can be predicted for any number of scenarios in association with cropping systems, management techniques, and erosion control practices. The erosion rate of ungauged basins can also be predicted based on the knowledge of the basin characteristics and local hydro-climate conditions (Garde and Kathyari, 1990).

The movement of sediment depends on geomorphologic and environmental surface factors such as topography and slope, drainage pattern, vegetation cover, soil texture, soil condition and rainfall duration (Walling, 1983). There are six main factors used to adequately represent all the surface characteristics in the RUSLE model and the relevant factors have been successfully derived from the remote sensing data, which is handled by Geographic information system (GIS) (Renard et al., 1998). The appropriate use of a complex deterministic model with a large number of input factors requires knowledge of the uncertainty of model outputs on the input factors. The accuracy of estimation in soil loss depends in part on how well the model factors describe the relevant characteristics of the basin. From this perspective, many studies have made efforts to improve the prediction capabilities by focusing on better estimations of the factor from the GIS data. GIS application has obvious advantages for rapid spatial risk assessment, particularly for remote rural areas (Sharma et al., 2001). This is especially true in the Korean water resources community, which stands on the brink of a new era of water and soil management with the advent of the broad GIS data sets. In typical fashion, the remotely sensed land surface data, such as soil texture map, Digital Elevation Map (DEM), and vegetation type map, were used as parameter inputs to RUSLE in this study. The model factors derived from the field investigation on a physical basis are, in most cases, reasonably given and the RUSLE model factors are not variable in a broad

HESSD

3, 135-157, 2006

\section{Scaling effect for soil loss in the RUSLE in Korea}

G.-S. Lee and K.-H. Lee

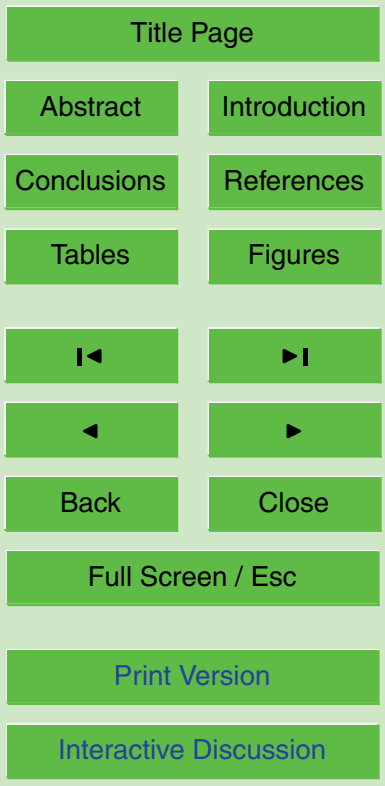

EGU 
range.

In the meanwhile, it is unlikely that the RUSLE model incorporates all spatial scales of the land surface map in need of application and this scaling issue is almost always arising when merging the geospatial data into the numerical model. The numerical grid

5 size is usually decided on a subjective and intuitive basis and the factors vary with the grid size in the RUSLE model.

Because the RUSLE is an empirically based soil loss model, it is essential to calibrate the model concerning both the grid size and model factors and we performed the model calibration with emphasis on the grid size in this study. To do this, the geospatial data of lower resolution (up to $200 \mathrm{~m}$ ) was, in turn, resampled from the $20 \mathrm{~m}$ resolution data and, then, converted to the corresponding model factors.

The objective of the present study is that, changing the scaling of geospatial data (20 m-200 m), a GIS spatial analysis was attempted to find the optimal resolution for the best fit with the observed soil loss data. The RUSLE model is facilitated for a basin, 15 So called Bosung located at southern part of Korea, to estimate soil loss for the year of 2002.

In the following section we briefly describe the study region and available data. In the third section, we explain the model setup and basic theory for the study, followed by the model results. In the last section we close the paper with summary and conclusions.

\section{Study region and data}

Unfortunately, in no field experiments to date, except the Bosung basin, have the unit sediment deposit required to verify the performance of the RUSLE model been made in Korea. Therefore the Bosung basin was chosen for the study site. The center of the Bosung basin is $127.03^{\circ} \mathrm{E} 34.80^{\circ} \mathrm{N}$, which is about $300 \mathrm{~km}$ south of the capital of Korea (Fig. 1). It covers about $274 \mathrm{~km}^{2}$ and the elevation is in the range of $121-794 \mathrm{~m}$. Because the Bosung basin is very steep $(0.22$ for $30 \mathrm{~m}$ DEM, while 0.14 for $130 \mathrm{~m}$ DEM), it was selected for a hydropower dam in 1937. Its annual average temperature

\section{Scaling effect for soil loss in the RUSLE in Korea}

\section{G.-S. Lee and K.-H. Lee}

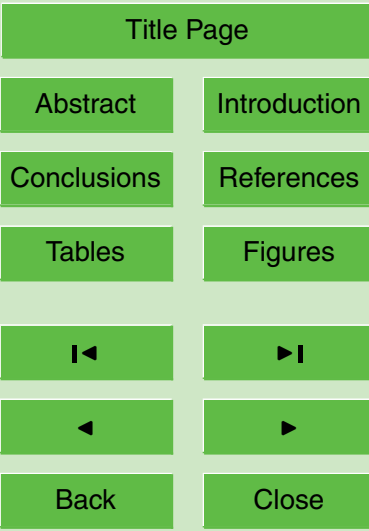

Full Screen / Esc

Print Version

Interactive Discussion 
and humidity are approximately $12^{\circ} \mathrm{C}$ and $75 \%$, respectively, and its annual average

precipitation $(=1495 \mathrm{~mm})$ is higher than the Korean national average $(=1283 \mathrm{~mm})$.

To extract the soil erodibility factor in RUSLE, a soil map is required and a scale of

3, 135-157, 2006 1:25000 was used. The soil data sampled at every $500 \mathrm{~m}$ was interpolated to construct 5 the soil texture map (KICT, 1992). A DEM map (20 m resolution) was constructed for the basin based on 1:5000 scale topographic map. Contour lines and river courses were digitized, rasterized, and then linearly interpolated. Thousands of points were collected using differentially corrected readings and calibrated to the ground sampling and then used for interpolation process. The final DEM was projected into Transverse Mercator (TM) coordinates to overlay other thematic maps as shown in Fig. 2.

The landcover map was constructed based on the commercially available Landsat ETM+ reflectance data. The land cover was classified into seven classes followed by USGS landcover classification system (Reed, 1997; Latifovic et al., 2004); water, urban, barren, swamp, grass, forest and agriculture. The Maximum Likelihood Method

15 (MLM) classification technique was applied to classify the land cover from the satellite image and consequently Table 1 presents the portion of each landcover type for the study site.

\section{Model and method}

As mentioned earlier, the RUSLE, modified from the USLE (Wischmeier and Smith, 20 1978), is designed to compute the average annual erosion on hillslopes but it is more diverse and extensive in function (Renard et al., 1998). In RUSLE, there are five factors (soil erodibility: $\mathrm{K}$, slope length: L, steepness: $\mathrm{S}$, cover management: $\mathrm{C}$, and support practice: $P$ ) derived form the surface characteristics and one factor (rainfall erosivity: $R$ ), which reflects the raindrop effect and the runoff rate, derived from the rainfall forcing 25 data. The Toxopeus equation, which is well known for its superiority in Korea (KICT,

\section{Scaling effect for soil loss in the RUSLE in Korea}

G.-S. Lee and K.-H. Lee

\section{Title Page}

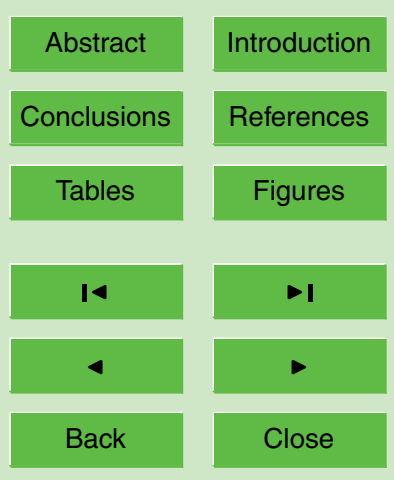

Full Screen / Esc

Print Version

Interactive Discussion 
1992), was used to calculate rainfall erosivity factor, $R$ as follows;

$R=38.5+0.35 \times \operatorname{Pr}$

$3,135-157,2006$

where, $R$ is rainfall erosivity factor (in $M J \cdot \mathrm{mm} \cdot \mathrm{ha}^{-1} \cdot \mathrm{yr}^{-1}$ ) and $P r$ is the annual average rainfall (in $\mathrm{mm} \cdot \mathrm{yr}^{-1}$ ).

5 The annual average precipitation for the time period of 1991-2001 was used to construct the spatially distributed rainfall map by the spline interpolation method. The corresponding average value of rainfall erosivity factor, $R$ was $436.912 \mathrm{MJ} \cdot \mathrm{mm} \cdot \mathrm{ha}^{-1} \cdot \mathrm{yr}^{-1}$ and standard deviation was $8.497 \mathrm{MJ} \cdot \mathrm{mm} \cdot \mathrm{ha}^{-1} \cdot \mathrm{yr}^{-1}$.

The K-factor reflects the ease with which the soil is detached by splash and surface 10 flow. In other words, it accounts for the influence of soil properties on soil loss on the hillslopes. Unstable soil aggregates and the corresponding base saturation are used to determine K (El-Swaify and Dangler, 1976). The K-factor is related to soil texture, organic matter content permeability, and other factors and it is basically derived from the soil type (Wischmeier, 1971), which is related to the grain size distribution and was derived from the Erickson's triangle diagram (Erickson, 1997) for the study. Soil loss is directly related to slope steepness (McCool et al., 1989) and the L- and S-factor accounts for the effect of slope length and slope gradient on erosion, respectively. A number of empirical equations for calculating the $L$ and $S$ factors have been suggested (McCool et al., 1989; Barsch, 1998; Yitayew et al., 1999) but the selection of a suitable 20 algorithm is dependent on the characteristics of the particular basin. The following equation (Desmet and Govers, 1996) is used for this study.

$L_{i j}=\frac{\left(A_{i j-i n}+D^{2}\right)^{m+1}-A_{i j-i n}^{m+1}}{D^{m+2} \times x_{i j}^{m} \times 22.13^{m}}$

where, $L_{i j}$ is the equivalent slope length factor for the cell, $A_{i j-i n}$ is the contributing area at the grid cell inlet, $D$ is the cell size, $m$ is the standard slope length exponent, $25 x_{i j}$ is the contour length $\left(\left|\sin \alpha_{i j}\right|+\left|\cos \alpha_{i j}\right|\right)$, and $\alpha_{i j}$ is the direction of cell. For the

\section{Scaling effect for soil loss in the RUSLE in Korea}

G.-S. Lee and K.-H. Lee

Title Page

Abstract

Introduction

Conclusions

References

Tables

Figures

14

4

Back

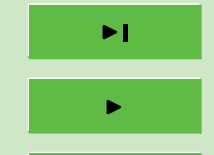

Close

Full Screen / Esc

Print Version

Interactive Discussion

EGU 
where the $\theta$ is the slope of cell (in degrees). In the RUSLE, the C-factor, which varies from near zero for well-protected land cover to 1 for barren areas (Singh, 1986), reflects 5 the abundance and type of the vegetation. The C-factor depends on the type of crop, the phenology, cultivation methods and management factors (Dissmeyer and Foster, 1981; Gilley, 1986). Table 2 shows the value of cover management factor, C, for each land cover type. The P-factor is a reflection of soil loss due to the flow pattern change, gradient, direction of surface runoff, and reduction of runoff rate resulting from variable cultivation (e.g. contouring, stripping, and terracing cropping etc.) (Renard and Foster, 1983). Table 3 shows the value of support practice factor, P, for various cases (KICT, 1992).

The cell-based representations of map features used in RUSLE offer analytical capabilities for continuous data and allow fast processing of map layer (Fernandez et al.,

15 2003). The mean annual gross soil erosion is calculated on the cell basis using the combination of the product of six factors as follows;

$A=R \times K \times L \times S \times C \times P$

where $A$ denotes the average soil loss due to water erosion (in ton $\cdot \mathrm{ha}^{-1} \cdot \mathrm{yr}^{-1}$ ) and the remaining factors are explained earlier. The $L, S, C$, and $P$ are all dimensionless. The basin sediment yield can be defined as the quantity of sediments which is routed to the basin outlet for a certain time period. Considering that only some of the eroded soils are routed to the basin outlet, knowing the ratio between the basin sediment yield at the basin outlet and soil erosion over the basin, which is called sediment delivery ratio (SDR), is important for the decision makers. However, the SDR involves numerous uncertainties including temporal discontinuity and spatial variability (Wolman, 1977; Walling, 1983). The RUSLE calculates soil loss forced by rainfall but doesn't take the SDR into account. To generate the sediment yield at the outlet, an Eq. (6) for SDR,

\section{Scaling effect for soil loss in the RUSLE in Korea}

G.-S. Lee and K.-H. Lee

Title Page

Abstract Introduction

Conclusions References

Tables Figures

14

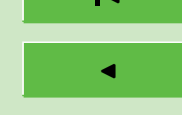

$\rightarrow 1$

Back

Close

Full Screen / Esc

Print Version

Interactive Discussion 
which is an empirical equation derived from the filed experimental data, was carried out in Korea (KICT, 1992).

$S D R=152.581 \times A_{\text {basin }}^{-0.577}$

$Y_{\gamma}=(R \times K \times L \times S \times C \times P) \times \operatorname{SDR}=A \times \operatorname{SDR}$

5 where $Y_{\gamma}$ denotes the unit (area $\mathrm{km}^{2}$ ) sediment yield and SDR is the sediment delivery ratio and $A_{\text {basin }}$ is the basin area. The SDR physically means the ratio of the sediment routed to the outlet over the basin (both overland and channel). The sediment is eventually deposited in the reservoir and the amount deposited in the reservoir, $V_{s}$ can be calculated as follows;

${ }_{10} V_{s}=E \frac{Y_{\gamma}}{\gamma_{m}}$

Where the $E$ denotes the trap efficiency (explained later), which is an indicator of the capability of capturing the transported sediment in the reservoir and the $\gamma_{m}$ denotes specific gravity of sediment. The sediment deposit $V_{s}$ is usually sampled via outflow load in the field experiment. Figure 2 presents a schematic plot for the general proce5 dure used in this study.

The erosivity factors in RUSLE was facilitated with a 2-D rainfall map (resolution $20 \mathrm{~m}$ ) interpolated by spline method on the basis of the four raingauge stations for the time period of the year 2002. The corresponding average value of the rainfall erosivity factor, $\mathrm{R}$ for each grid comes out to be $436.912\left(\mathrm{MJ} \cdot \mathrm{mm} \cdot \mathrm{ha}^{-1} \cdot \mathrm{yr}^{-1}\right)$ with the standard 20 deviation (SD)( This is a SD of the spatially distributed rainfall erosivity factor, $R$ ), 8.497 (in $M J \cdot \mathrm{mm} / \mathrm{ha} / \mathrm{yr}$ ).

As shown in Table 4, the rainfall erosivity factor, $R$ is in the range of $410-452$ and it implies that the rainfall in the Bosung basin is spatially homogeneous in relative terms. The K-factor comes out the ranges from $0.10-0.50$ on the basis of the soil map. The mean and SD of the soil erodibility factor, $\mathrm{K}$ is 0.286 and 0.114 , respectively. The

HESSD

3, 135-157, 2006

\section{Scaling effect for soil loss in the RUSLE in Korea}

G.-S. Lee and K.-H. Lee

Title Page

Abstract

Introduction

Conclusions

References

Tables

Figures

14

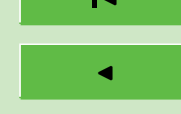

$\rightarrow 1$

Back

Close

Full Screen / Esc

Print Version

Interactive Discussion

EGU 
L-factor and S-factor are calculated separately for independent risk assessment. The mean values of the L- and S- factor are 2.448 and 3.593 (Table 4), respectively, while the SD of the L- and S- factor are 1.751 and 3.108, respectively. The SD of L- and $\mathrm{S}$ - factor is relatively large and it is a direct reflection of high topographic variation in

5 Bosung basin because over $67 \%$ of the basin is mountainous and forest-covered (see Table 1). The average $\mathrm{C}$ - factor was evaluated as 0.150 and it is considered to be reasonable with $75 \%$ of forest and grass (see Table 1 ) in the basin, while The P-factor factor was estimated as 0.808 , reflecting the dominant forest and steep gradient. The $\mathrm{C}$ - and $\mathrm{P}$ - factors are calculated from the landcover map and DEM on the basis of the 10 field experimental results (KICT, 1992).

In an attempt to calibrate the simulated soil loss by RUSLE, the GIS data is incrementally resampled up to $200 \mathrm{~m}$ resolution by $10 \mathrm{~m}$ interval.

\section{Results and discussion}

We compared modeled to measured soil loss for the location at the outlet by using SDR 15 and trap efficiency. The RUSLE calculated the annual average soil loss (for the basin) from Eq. (4) using the six factors and it is estimated as $A=139.7$ (in ton $\mathrm{ha}^{-1} \cdot \mathrm{yr}^{-1}$ ). It is, however, very difficult to measure the soil loss in a basin. Instead, the sediment deposit, $V_{s}=200 \mathrm{~m}^{3} \cdot \mathrm{km}^{-2} \cdot \mathrm{yr}^{-1}$, which is readily sampled in the field experiment, is reasonably converted to the sediment yield, $Y_{r}=314.3$ ton $\cdot \mathrm{km}^{-2} \cdot \mathrm{yr}^{-1}$. To obtain sediment yield, $Y_{r}$ 20 from Eq. (7), the experimental value of 0.7 for trap efficiency and 1.1 ton. $\mathrm{m}^{-3}$ of bulk density (KICT, 1992) are used for this study. The sediment yield, $Y_{r}$ is reasonably converted to the soil loss generation, $\mathrm{A}\left(=52.6 \mathrm{in}\right.$ ton $\left.\cdot \mathrm{ha}^{-1} \cdot \mathrm{yr}^{-1}\right)$ using the value of 5.98 (in \%) for SDR (Eq. 5).

There are potential error sources in the measured soil loss generation, which include measurement error, the natural variability of particle size, and the electronic calibration of echo sounding. They might result in some uncertainties in the selection of optimal grid size explained later.

\section{Scaling effect for soil loss in the RUSLE in Korea}

G.-S. Lee and K.-H. Lee

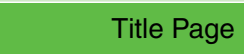

Abstract

Conclusions

Tables

14

4

Back

Full Screen / Esc

Print Version

Interactive Discussion 
Because there is large discrepancy (157\% overestimated) between the observed and the estimated, the simulated soil loss by RUSLE is not acceptable. In fact, the GIS-based simulation output is strongly dependent on the grid size but there is no fast and solid rule for selecting the grid size. The grid size is diversely selected depending 5 on the basin characteristics and modeling complexity. Figure 3 shows the sensitivity of the RUSLE factors normalized by maximum value of each factor, which is specified on the vertical axis as a function of the spatial resolution on the horizontal axis. It is general feature that, for estimating soil loss in the RUSLE model, the L- and Sfactors are very sensitive to the spatial resolution, while the remaining factors are not 10 sensitive. It implies that the DEM information, which is directly transformed to L- and S- factors, is crucial in calculating soil loss and caution needs to be taken in selecting the DEM grid size. The L- and S- factors are large at higher resolution and vice versa. As mentioned earlier, the SD of L- and S- factor is large because of high topographic variation in Bosung basin and the topographic effect in Eqs. (2) and (3) is smoothed out 15 by averaging many different cells at lower resolution. Figure 4 shows the simulated soil loss generation as a function of the spatial resolution and the vertical line (dotted line) represents the optimal point for the best fit. It is also generally found that the soil loss responses are nonlinearly related to the spatial resolution. There is some evidence that the variation of soil loss (slope) is large at higher resolution but it is fast decreasing 20 as the resolution decreases. The simulated soil loss of $52.8 \mathrm{ton} \cdot \mathrm{ha}^{-1} \cdot \mathrm{yr}^{-1}$ by RUSLE at $125 \mathrm{~m}$ shows best fit with the sampled soil loss of 52.6 ton.ha ${ }^{-1} \cdot \mathrm{yr}^{-1}$ and Fig. 5 shows the corresponding 2-D soil loss map simulated by the RUSLE at $125 \mathrm{~m}$ resolution.

A strong correspondence between areas of high relief on the DEM and high soil loss is pronounced in Fig. 5.

25 It seems that the model could be fit to observations by adjusting either SDR or the RUSLE factors. As mentioned earlier, either SDR or the RUSLE model factors are extracted from the field investigation on a physical basis and they are reasonably given in reality. On the basis of this fact, it is hard to conceive that the RUSLE model factors are widely changeable (In some case, unrealistic values of SDR or factors are given to
HESSD

$3,135-157,2006$

\section{Scaling effect for soil loss in the RUSLE in Korea}

G.-S. Lee and K.-H. Lee

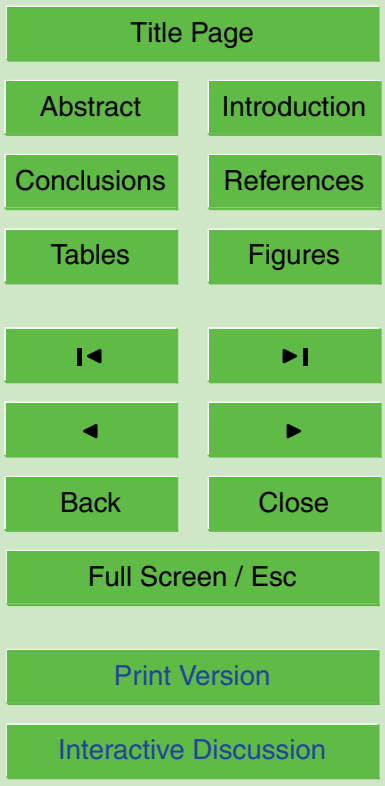

EGU 
fit the observations). Alternatively the RUSLE scale is chosen to adjust observations in this study. But it is hard to conclude that the optimal resolution for the best fit in the RUSLE model is $125 \mathrm{~m}$ in general, because the model output is highly dependent on the selection of model, the quality of geospatial data, and the basin characteristics. Hence 5 the optimal spatial scale $125 \mathrm{~m}$ may not work in every watershed and the procedure need to be done for every new basin of interest, but the method used to determine the optimal scale should work anywhere.

\section{Summary and conclusions}

This study describes the application of the RUSLE model, to quantify soil loss in a Bo10 sung basin located at southern part of Korea, using the GIS skill. The strategy adopted here is, firstly, to calculate six RUSLE factors using distributed GIS data (e.g. soil, land cover, and DEM ) to adequately represent the surface characteristics and, secondly, to estimate spatial distribution of soil loss in the basin, and, lastly, to find a optimal numerical resolution for the RUSLE model, minimizing the difference between the observed and simulated. The primary conclusions of the present study are as follows:

- The spatial resolution is very sensitive to the estimation of soil loss in the RUSLE model. It implies that caution needs to be taken in selecting the grid size for estimating soil loss using numerical modeling approach.

- The L- and S- factor, which is a reflection of the topographical effect, are sensitive to the estimation of soil loss in the RUSLE model.

- The optimum resolution for soil loss comes out to be $125 \mathrm{~m}$ in this study but it might be dependent on the selection of model, the quality of geospatial data, and the basin characteristics.

It is anticipated that the approach suggested herein will provide a useful method for

\section{Scaling effect for soil loss in the RUSLE in Korea}

G.-S. Lee and K.-H. Lee

Title Page

Abstract

Introduction

Conclusions

References

Tables

Figures

14

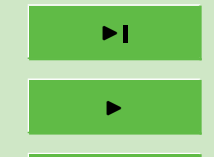

4

Back

Close

Full Screen / Esc

Print Version

Interactive Discussion 
eventually improve the prediction of soil loss in a basin scale. Also the method is relatively simple and has wide applicability.

Acknowledgements. This study was supported by Korea Water Resources Corporation project \# KIWE-CHR-04-4.

\section{References}

Bartsch, P.: Modelling Soil Loss to determine water erosion risk at Camp Williams national guard base, Ph.D. Dissertation, UTAH State University, 1998.

Brown, L. C. and Foster, G. R.: Storm erosivity using idealized intensity distributions, Trans, ASAE, 30, 579-591, 1987.

10 Ouyang, D.: Modeling Sediment and Phosphorus loading in a small agricultural watershed, Ph.D. Dissertation, Department of Crop and Soil Science, Michigan State University, 2001.

Desmet, P. J. J. and Govers, G.: A GIS-procedure for the automated calculation of the USLE LS-factor on topographically complex landscape units, J. Soil and Water Conservation, 51(5), 427-433, 1996.

15 Dissmeyer, G. E. and Foster, G. R.: Estimating the cover management factor in the USLE for forest conditions, J. Soil and Water Conservation, 36(4), 235-240, 1981.

El-Swaify, S. A. and Dangler, E. W.: Erodibilities of selected tropical soils in relation to structural and hydrologic parameters, in: Soil Erosion Prediction and Control, edited by: Foster, G. R., Soil and Water Conservation Society, Ankeny, IA, USA, 105-114, 1976.

Erickson, A. J.: Aids for estimating soil erodibility $-\mathrm{K}$ value class and soil loss tolerance, USDA, Soil Conservation Service, Salt Lake City, Utah, 1997.

Fernandez, C., Wu, J. Q., McCool, D. K., and Stockle, C. O.: Estimating water erosion and sediment yield with GIS, RUSLE, and SEDD, J. Soil Water Conservation, 58, 128-136, 2003.

Garde, R. J. and Kathyari, U. C.: Erosion prediction models for large catchments, in: Proceedings of the International Symposium on Water Erosion, Sedimentation, and Resource Conservation, Dehradun, India, 89-102, 1990.

Gilley, J. E., Finkner, S. C., Spomer, R. G., and Mielke, L. N.: Runoff and erosion as affected by crop, Trans. Amer. Assoc. Agricultural Eng., 29(1), 157-160, 1986.

Korea Institute of Construction Technology (KICT): The development of selection standard for

$3,135-157,2006$

\section{Scaling effect for soil loss in the RUSLE in Korea}

G.-S. Lee and K.-H. Lee

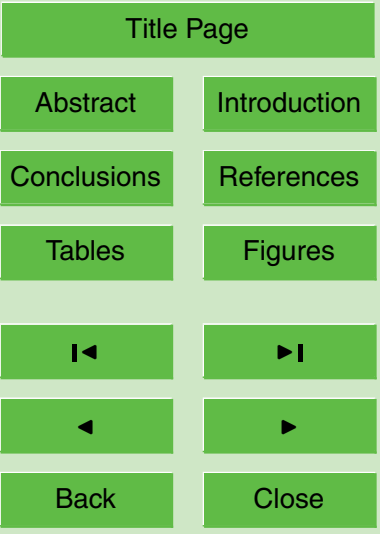

Full Screen / Esc

Print Version

Interactive Discussion

EGU 
calculation method of unit sediment yield in river, KICT 89-WR-113 Research Paper (in Korean), 1992.

Latifovic, R., Zhu, Z. L., Cihlar, J., Giri, C., and Olthof, I.: Land cover mapping of North and Central America - Global Land Cover 2000, Remote Sens. Environ., 89(1), 116-127, 2004.

5 McCool, D. K., Foster, G. R., Mutchler, C. K., and Meyer, L. D.: Revised Slope Length Factor the Universal Soil Loss Equation. Transactions of the American Society of Agricultural Engineers, 32(5), 1571-1576, 1989.

Morgan, R. P. C.: Soil Erosion and Conservation. Addison Wesley Longman Limited, 1995.

Nearing, M. A.: A single continuous function for slope steepness influence on soil loss, Soil Sci.

$10 \quad$ Soc. Amer. J., 61, 917-919, 1997.

Pimentel, D.: World Soil Erosion and Conservation, Cambridge University Press, Cambridge, England, pp. 349, 1993.

Reed, B.: Applications of the U.S. Geological Survey's global land cover product, Acta Astronautica, 41(4-10), 671-680, 1997.

15 Renard, K. G. and Foster, G. R.: Soil Conservation-Principles of erosion by water, in: Dryland Agriculture, edited by: Dregne, H. E. and Willies, W. O., American Society of Agronomy, Soil Sci. Soc. Amer., Madison, WO, USA, 155-176, 1983.

Renard, K. G., Foster, G. R., Weesies, G. A., McCool, D. K., and Yoder, D. C.: Predicting soil erosion by water: a guide to conservation planning with Revised Universal Soil Loss

20 Equation (RUSLE), Agriculture, Handbook No. 703, usda, ARS, Washington, DC, 1998.

Roose, E. J.: Application of the Universal Soil Loss Equation of Wischmeier and Smith in West Africa, in: Conservation and Soil Management in the Humid Tropics, edited by: Greenland, J. and Lal, R., Wiley, Chichester, England, 177-187, 1977.

Sharma, T., Satya Kiran, P. V., Singh, T. P., Trivedi, A. V., and Navalgund, R. R.: Hydrologic response of a watershed to land use changes: a remote sensing and GIS approach, Int. J. Remote Sens., 22, 2095-2108, 2001.

Singh, A.: Change detection in the tropical forest environment of northeastern India using LANDSAT, Remote Sensing and Tropical Land Management, Plymouth, John Wiley and Sons Ltd., 237-254, 1986.

30 Walling, D. E.: The sediment delivery problem, J. Hydrol., 65, 209-237, 1983.

Wischmeier, W. H.: A Soil Erodibility Nomograph for Farmland and Construction sites, J. Soil and Water Conservation, 26, 189-193, 1971.

Wischmeier, W. H. and Smith, D. D.: Predicting Rainfall Erosion Losses - A Guide to Con-

\section{Scaling effect for soil loss in the RUSLE in Korea}

G.-S. Lee and K.-H. Lee

\section{Title Page}

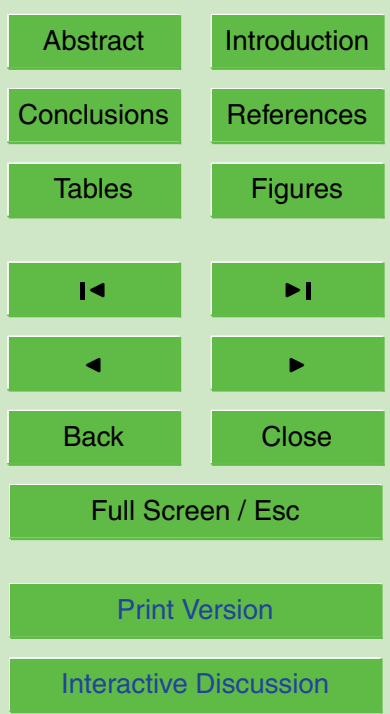

EGU 
servation Planning, USDA-Agriculture Handbook No. 537, U.S. Government Printing Office, Washington, DC, 1978.

Wolman, M. G.: Changing needs and opportunities in the sediment field, Water Resour. Res., 13, 50-59, 1977.

5 Yitayew, M., Pokrzywka, S. J., and Renard, K. G.: Using GIS for facilitating erosion estimation, Appl. Eng. Agric., 15, 295-301, 1999.

\section{HESSD}

$3,135-157,2006$

\section{Scaling effect for soil loss in the RUSLE in} Korea

G.-S. Lee and K.-H. Lee

\section{Title Page}

Abstract

Conclusions

Tables

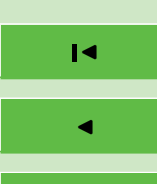

Back
Introduction

References

Figures

\section{I}

$\checkmark$

Close

Full Screen / Esc

Print Version

Interactive Discussion 
3, 135-157, 2006

\section{Scaling effect for soil loss in the RUSLE in}

Korea

G.-S. Lee and K.-H. Lee

Table 1. Portion of each landcover type for Bosung basin.

\begin{tabular}{ccc}
\hline Class & Count of cells $(20 \mathrm{~m})$ & Percent $(\%)$ \\
\hline Water & 5514 & 1.81 \\
Urban & 3534 & 1.16 \\
Barren & 2080 & 0.68 \\
Swamp & 98 & 0.03 \\
Grass & 20997 & 6.90 \\
Forest & 205803 & 67.59 \\
Agriculture & 66469 & 21.83 \\
$\Sigma$ & 304495 & 100.00 \\
\hline
\end{tabular}

Title Page

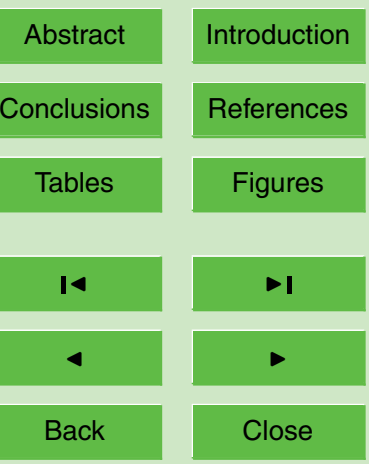

Full Screen / Esc

Print Version

Interactive Discussion 
3, 135-157, 2006

\section{Scaling effect for soil loss in the RUSLE in}

Korea

G.-S. Lee and K.-H. Lee

Table 2. C-factor depending on the land cover types.

\begin{tabular}{cc}
\hline Land cover & C \\
\hline Water & 0.000 \\
Urban & 0.002 \\
Barren & 0.500 \\
Grass & 0.050 \\
Forest & 0.004 \\
Agriculture & 0.300 \\
\hline
\end{tabular}

Title Page

Abstract

Introduction

Conclusions References

Tables

Figures

14

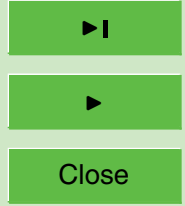

Back

Close

Full Screen / Esc

Print Version

Interactive Discussion 


\section{HESSD}

3, 135-157, 2006

\section{Scaling effect for soil loss in the RUSLE in}

Korea

G.-S. Lee and K.-H. Lee

Table 3. The P-factor depending on the cultivation types (e.g. contouring, stripping, and terracing etc.) and the slope (KICT, 1992).

\begin{tabular}{cccc}
\hline Slope (\%) & Contouring & Stripping & Terracing \\
\hline $0.0-7.0$ & 0.55 & 0.27 & 0.10 \\
$7.0-11.3$ & 0.60 & 0.30 & 0.12 \\
$11.3-17.6$ & 0.80 & 0.40 & 0.16 \\
$17.6-26.8$ & 0.90 & 0.45 & 0.18 \\
$26.8>$ & 1.00 & 0.50 & 0.20 \\
\hline
\end{tabular}

Title Page

Abstract

Conclusions

Tables

References

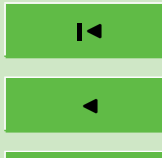

Back

Full Screen / Esc

Print Version

Interactive Discussion 
3, 135-157, 2006

\section{Scaling effect for soil loss in the RUSLE in Korea}

\section{G.-S. Lee and K.-H. Lee}

Table 4. Basic statistics for the RUSLE factors and soil loss in Bosung basin at $20 \mathrm{~m}$ resolution.

\begin{tabular}{lrrrr}
\hline & Min & Max & Mean & SD \\
\hline Rainfall erosivity factor (R) & 410.91 & 452.08 & 436.91 & 8.50 \\
Soil erodibility factor (K) & 0.10 & 0.50 & 0.29 & 0.11 \\
Slope steepness factor (L) & 0.77 & 9.77 & 2.45 & 1.75 \\
Slope steepness factor (S) & 0.05 & 14.95 & 3.59 & 3.11 \\
Cover management factor (C) & 0.00 & 0.50 & 0.15 & 0.09 \\
Support practice factor (P) & 0.10 & 1.00 & 0.81 & 0.36 \\
Soil loss (A) & 0.00 & 3721.39 & 139.66 & 208.97 \\
\hline
\end{tabular}

Title Page

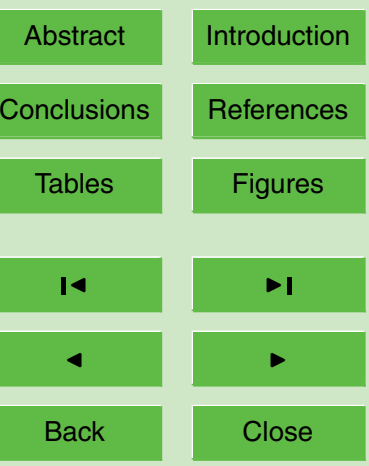

Full Screen / Esc

Print Version

Interactive Discussion 


\section{HESSD}

$3,135-157,2006$

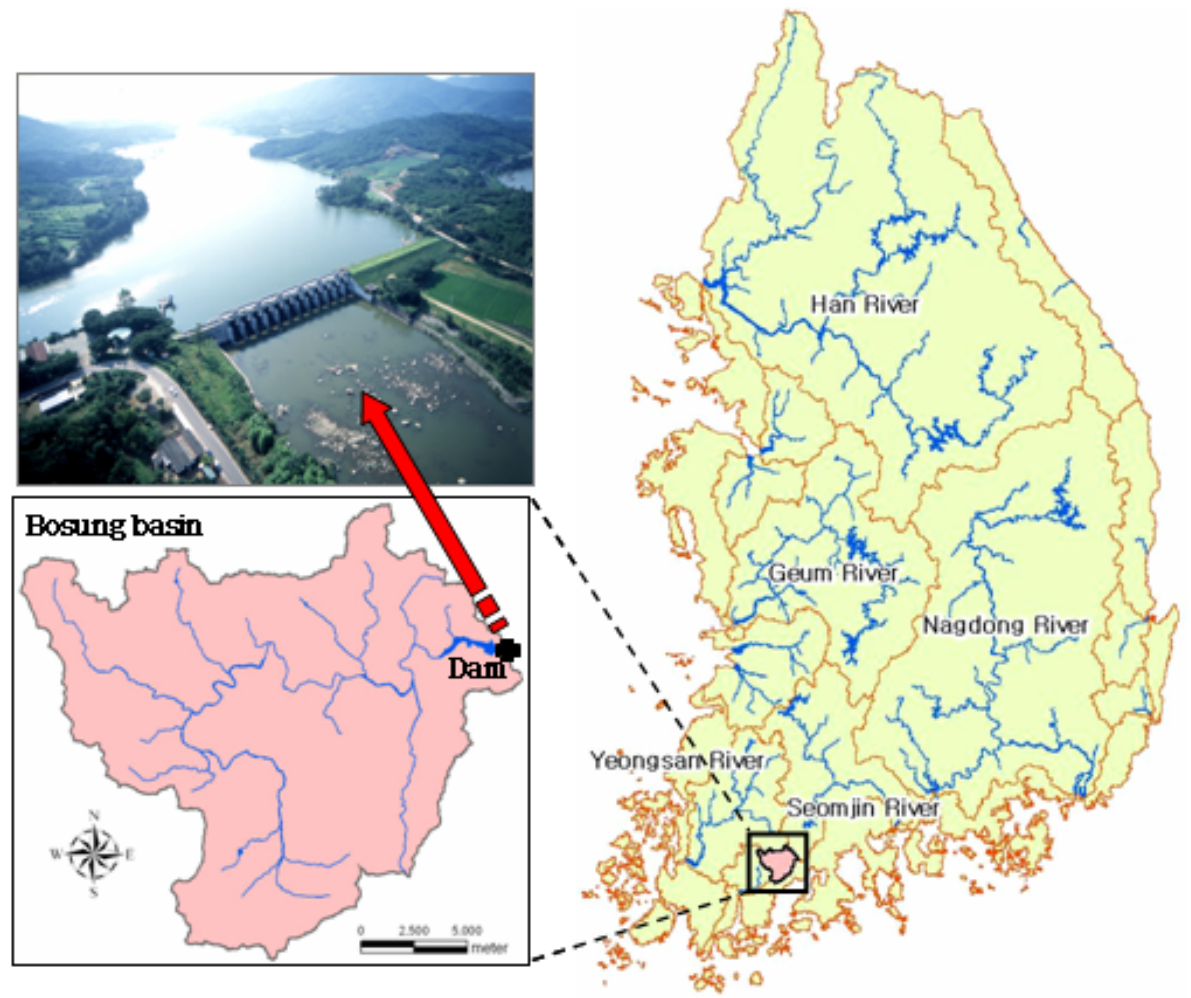

\section{Scaling effect for soil loss in the RUSLE in Korea}

G.-S. Lee and K.-H. Lee

Title Page

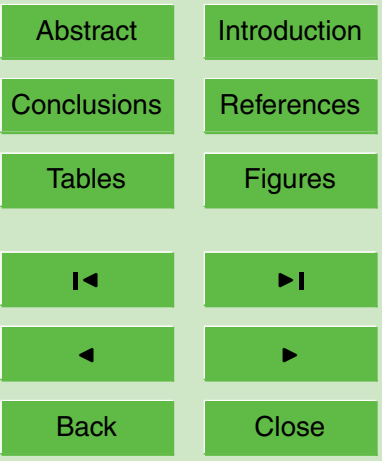

Full Screen / Esc

Print Version

Fig. 1. Study region. The Bosung basin is located at southern part of Korea.

Interactive Discussion

EGU 


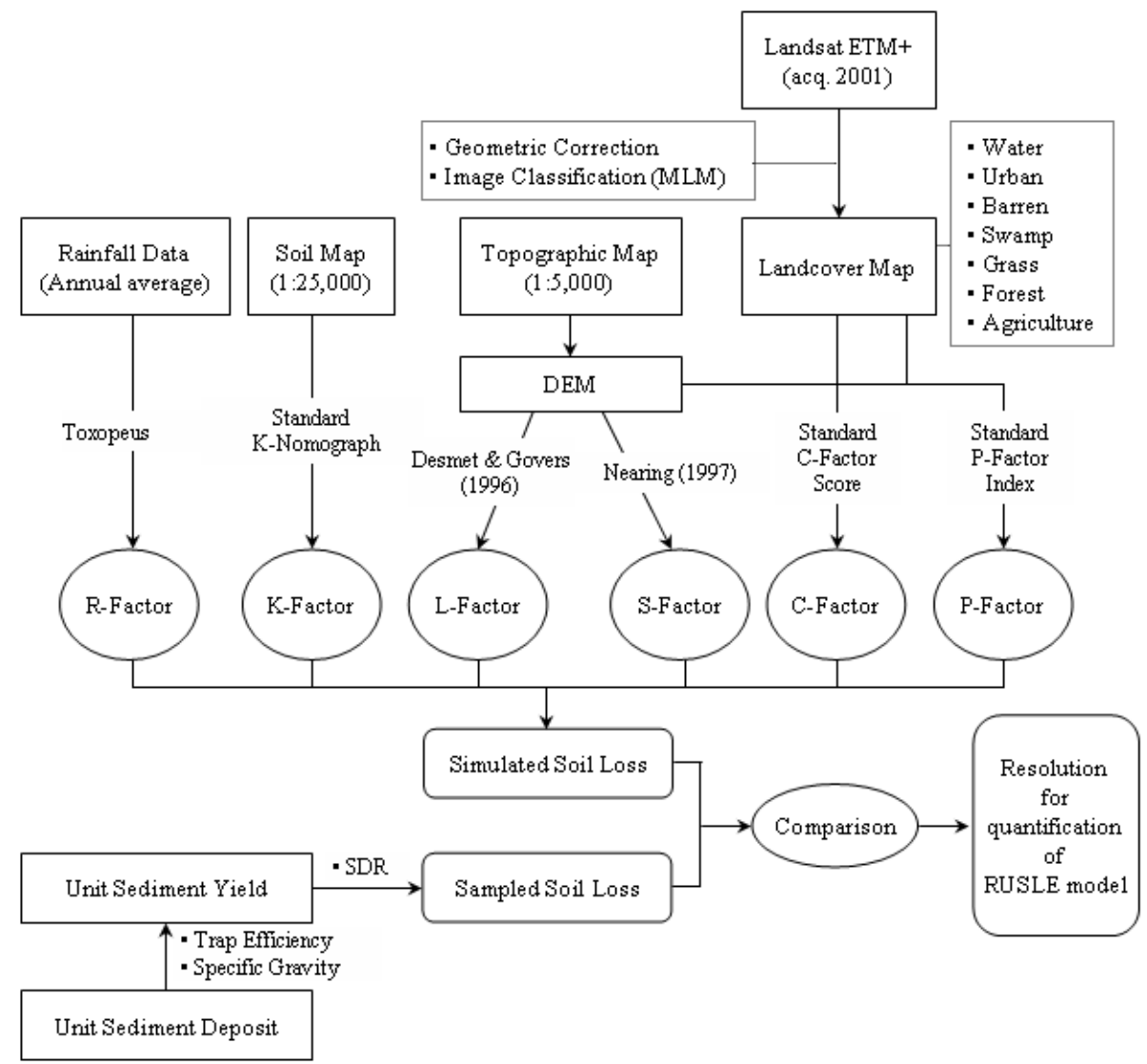

3, 135-157, 2006

\section{Scaling effect for soil loss in the RUSLE in Korea}

G.-S. Lee and K.-H. Lee

Title Page

\begin{tabular}{|c|c|}
\hline Abstract & Introduction \\
\hline Conclusions & References \\
\hline Tables & Figures \\
\hline I4 & \\
\hline 4 & \\
\hline Back & Close \\
\hline
\end{tabular}

Full Screen / Esc

Print Version

Interactive Discussion

EGU 


\section{HESSD}

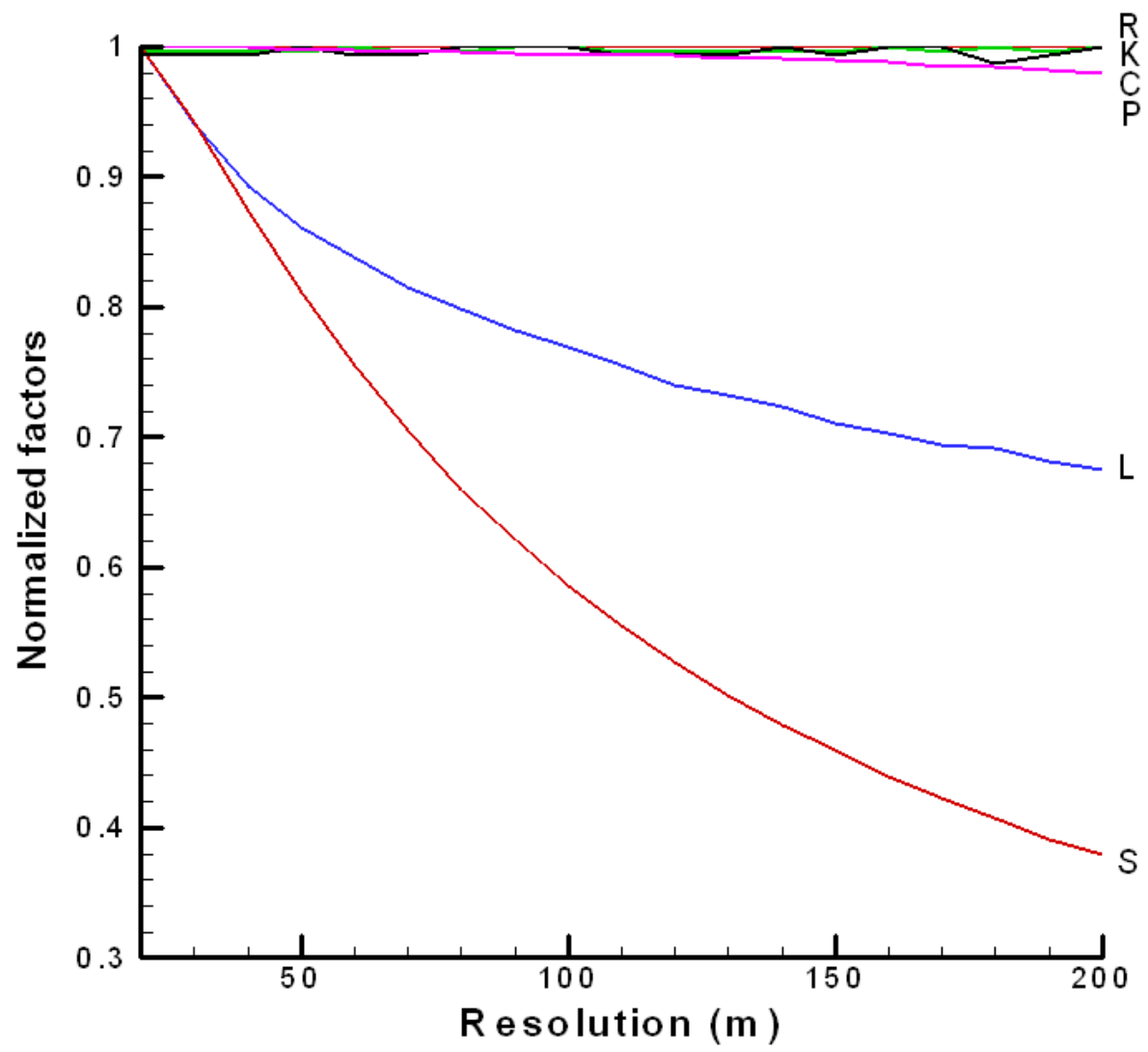

3, 135-157, 2006

\section{Scaling effect for soil loss in the RUSLE in Korea}

\section{G.-S. Lee and K.-H. Lee}

\section{Title Page}

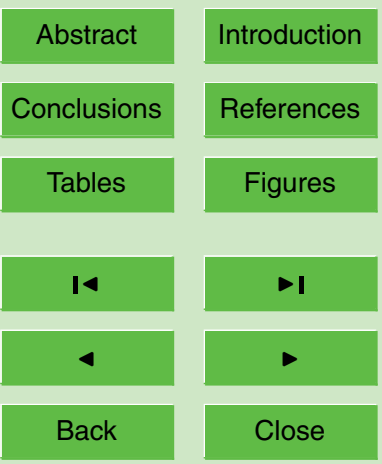

\section{Full Screen / Esc}

Print Version

Fig. 3. The sensitivity of the RUSLE factors normalized by maximum value of each factor. The L- and S- factors are sensitive to the spatial resolution for estimating soil loss. 
3, 135-157, 2006

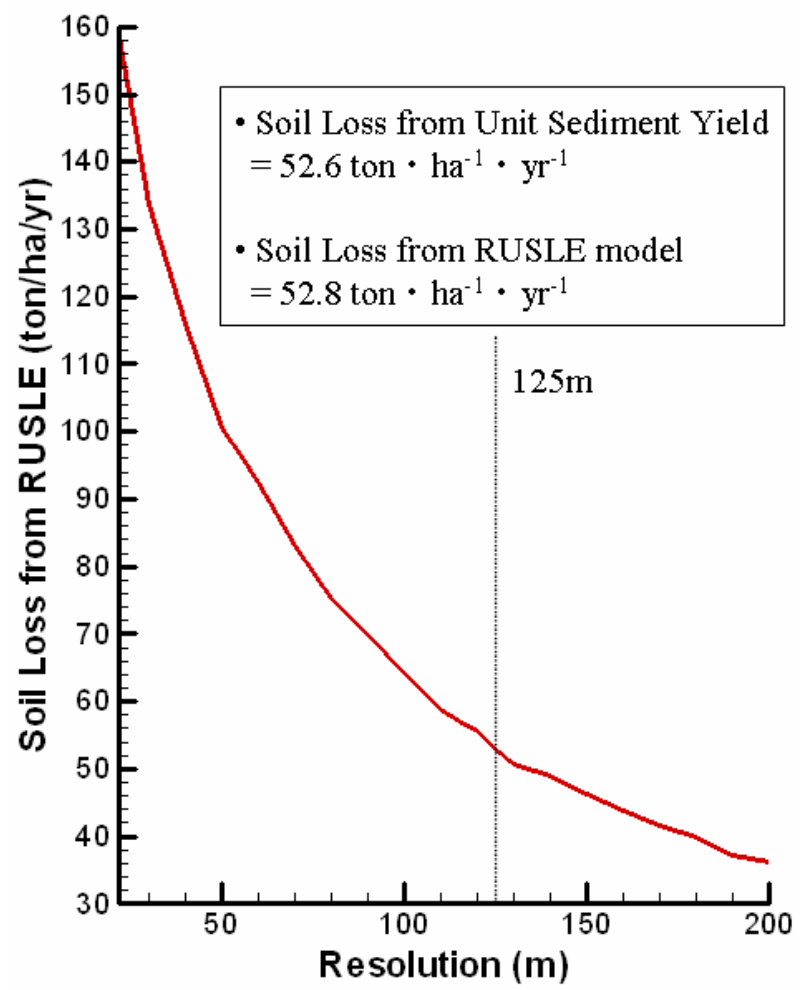

\section{Scaling effect for soil loss in the RUSLE in Korea}

G.-S. Lee and K.-H. Lee

Title Page

Abstract

Conclusions

Tables

Figures

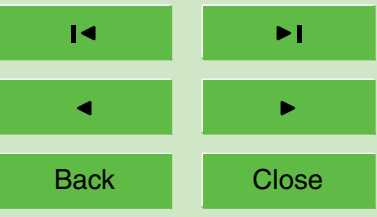

Full Screen / Esc

Print Version

Interactive Discussion the simulated soil loss by the RUSLE is $125 \mathrm{~m}$ for the best fit with the observed. 


\section{HESSD}

$3,135-157,2006$
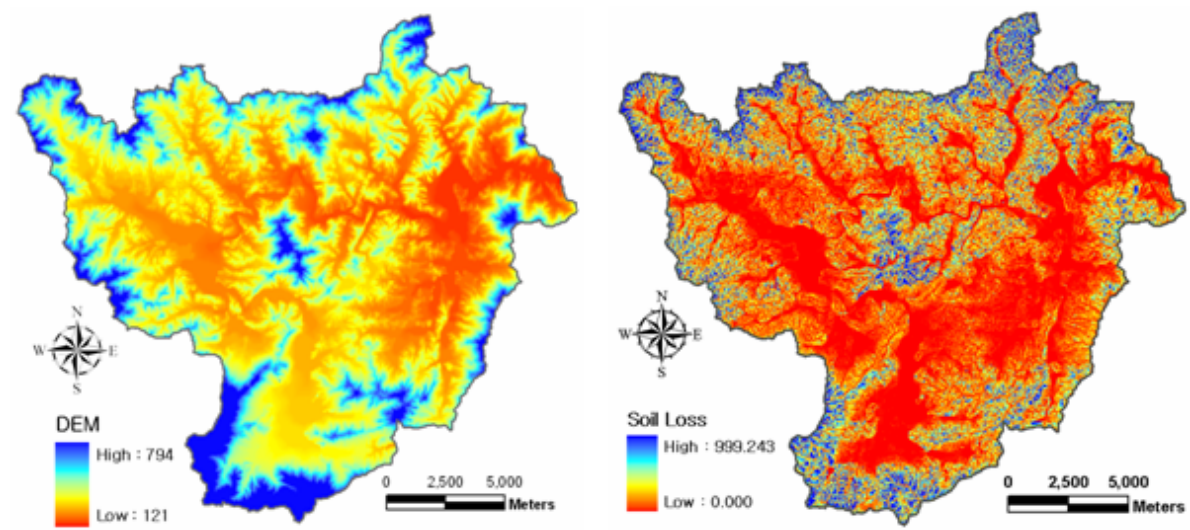

\section{Scaling effect for soil loss in the RUSLE in Korea}

G.-S. Lee and K.-H. Lee

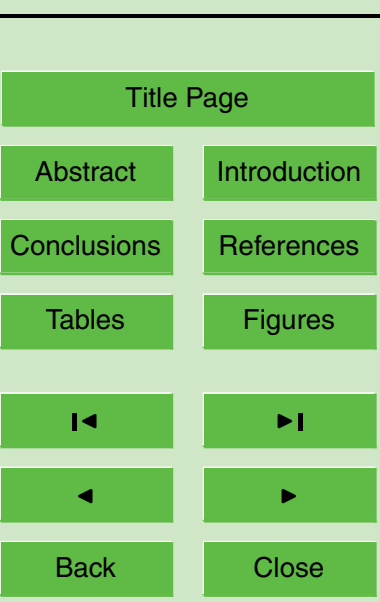

Fig. 5. The simulated 2-D soil loss map at $125 \mathrm{~m}$ resolution along with 2-D DEM in $30 \mathrm{~m}$ resolution. The spatial average value is 52.8 (in ton $\cdot \mathrm{ha}^{-1} \cdot \mathrm{yr}^{-1}$ ).

Full Screen / Esc

Print Version

Interactive Discussion 